[Supporting Information]

\title{
Ring-Expanding Olefin Metathesis: A Route to Highly Active Unsymmetrical Macrocyclic Oligomeric Co-Salen Catalysts for the Hydrolytic Kinetic Resolution of Epoxides
}

\author{
Xiaolai Zheng, ${ }^{\dagger}$ Christopher W. Jones, ${ }^{*}{ }^{\dagger, *}$ and Marcus Weck ${ }^{*}, \dagger$ \\ ${ }^{\dagger}$ School of Chemistry and Biochemistry, and ${ }^{\ddagger}$ School of Chemical \& Biomolecular \\ Engineering, Georgia Institute of Technology, Atlanta, GA 30332-0400
}

\section{Contents:}

$1 \quad$ Materials and Methods

2 Synthetic Procedures

2.1 General Procedures for the Hydrolytic Kinetic Resolution - (S)-Allyl Glycidyl Ether (Table 1, Entry 3)

2.2 (R)-1,2-Epoxyhexane (Table 1, Entry 1)

2.3 (S)-Epichlorohydrin (Table 1, Entry 2)

2.4 (S)-Glycidyl Phenyl Ether (Table 1, Entry 4)

2.5 (R)-Styrene Oxide (Table 1, Entry 5)

2.6 (R)-tert-Butyloxirane (Table 1, Entry 6)

3 In situ ${ }^{1} \mathrm{H}$ NMR Spectra of the Ring-Expanding Olefin Metathesis of 7

$4 \quad$ GPC Traces

\section{References}




\section{Materials and Methods}

Reagents were purchased from Aldrich, Acros, or Alfa, and used as received unless noted below. Dichloromethane and THF were dried by passing through columns of activated cupper and alumina successively. 3-tert-Butyl-2,5-dihydroxybenzaldehyde, ${ }^{1}$ cyclooct-4-enecarboxylic acid, ${ }^{2,3} \quad(1 R, 2 R)$-1,2-diaminocyclohexane mono(hydrogen chloride), ${ }^{4}$ and the third generation Grubbs catalyst ${ }^{5}$ were prepared according to published procedures.

Melting points were determined with a Laboratory Devices MEL-TEMP II apparatus and are uncorrected. NMR spectra were acquired with a Varian Mercury 400 $\left({ }^{1} \mathrm{H}, 400.0 \mathrm{MHz} ;{ }^{13} \mathrm{C}, 100.6 \mathrm{MHz}\right)$ or a Varian Mercury $300\left({ }^{1} \mathrm{H}, 300.0 \mathrm{MHz} ;{ }^{13} \mathrm{C}, 75.5\right.$ $\mathrm{MHz}$ ) spectrometer. Chemical shifts are reported in $\mathrm{ppm}$ and referenced to the residual nuclei in the corresponding deuterated solvents. IR and UV-vis spectra were recorded with a Shimadzu FTIR-8400S and a Shimadzu UV-2401PC spectrometer, respectively. Mass spectra were recorded with a VG 7070 EQ-HF hybrid tandem mass spectrometer or an Applied Biosystems 4700 spectrometer. For MALDI-TOF measurements, the instrument was tuned and calibrated using a series of peptides as standards. The spectra were recorded in both reflector and linear modes using dithranol or $\alpha$-cyano-4hydroxycinnamic acid (CHCA) as the matrix. Gel permeation chromatography (GPC) analyses were performed with American Polymer Standards columns (100, 1,000, $100,000 \AA$ A linear mixed bed) equipped with a Waters 510 or a Shimadzu LC-10AD pump and a UV detector. Poly(styrene)s ( $M_{\mathrm{n}}$ ranging from 580 to 7,500,000) were employed as standards for calibration and THF was used as a mobile phase (flow rate at $1.0 \mathrm{~mL} / \mathrm{min}$ ). 
Enantiomeric excesses (ee's) were determined by capillary gas-phase chromatography (GC) analysis or by high performance liquid-phase chromatography (HPLC). The chiral GC analysis was performed on a Shimadzu GC 14-A instrument equipped with an FID detector as well as a Chiraldex $\gamma$-TA column $(30 \mathrm{~m} \times 0.25 \mathrm{~mm} \times$ $0.25 \mu \mathrm{m}$ film thickness, Advanced Separation Technologies, Inc.) or a $\beta$-Dex 120 column (30 $\mathrm{m} \times 0.25 \mathrm{~mm} \times 0.25 \mu \mathrm{m}$ film thickness, Supelco) with helium as the carrier gas. The

chiral HPLC analysis was carried out with a Chiracel OD column $(24 \mathrm{~cm} \times 0.46 \mathrm{~mm}$, Chiral Technologies, Inc.) equipped with a Waters 510 pump (flow rate at $1 \mathrm{~mL} / \mathrm{min}$ ) and a UV detector.

\section{Synthetic Procedures}

\subsection{General Procedures for the Hydrolytic Kinetic Resolution - (S)-Allyl Glycidyl}

\section{Ether (Table 1, Entry 3)}

Method A: Pre-oxidation of $(R, R)-\mathbf{4}$ with acetic acid (AcOH). The Co(II)(salen) pre-catalyst $(R, R)-4(3.5 \mathrm{mg}, 0.005 \mathrm{mmol}$ on the basis of cobalt, $0.01 \mathrm{~mol} \%)$ was dissolved in dichloromethane $(1 \mathrm{~mL})$ in a $25 \mathrm{~mL}$ flask. Glacial acetic acid $(10 \mu \mathrm{L})$ was added to the solution and the mixture was stirred in the open air for $30 \mathrm{~min}$, during which time the color changed from deep red to dark brown. The solvent and the excess acetic acid were roughly removed by rotary evaporation. The residue was pumped under vacuum (1 mbar) for $5 \mathrm{~min}$ to give $(R, R)-\mathbf{4}(\mathrm{OAc})$ as a dark brown solid. The activated catalyst was dissolved in racemic allyl glycidyl ether $(5.71 \mathrm{~g}, 50 \mathrm{mmol}$ ) (in the cases of kinetic studies, chlorobenzene was added as an internal reference for the GC analysis). The flask was immersed into a water bath at ambient temperature and deionized water 
( $0.54 \mathrm{~mL}, 30 \mathrm{mmol}, 0.60$ equiv) was added to the system to start the reaction. The resolution process was monitored by chiral GC method. After the reaction was stirred at rt for $12 \mathrm{~h}$, the remaining epoxide was vacuum-transferred $\left(40{ }^{\circ} \mathrm{C}, 0.15 \mathrm{mbar}\right)$ to a receiving flask pre-cooled at $-78{ }^{\circ} \mathrm{C}$. The recovered epoxide was passed through a plug of silica gel packed in a Pasteur pipet to give (S)-allyl glycidyl ether as a clear colorless liquid $(2.73 \mathrm{~g}, 48 \%)$ in $>99 \%$ ee according to chiral GC analysis $\left(\gamma\right.$-TA, $80{ }^{\circ} \mathrm{C}$, isothermal, $t_{\mathrm{R}}(S$, major $)=8.8 \mathrm{~min}, t_{\mathrm{R}}(R$, minor $\left.)=7.7 \mathrm{~min}\right)$.

Method B: Pre-oxidation of $(R, R)-4$ with $p$-toluenesulfonic acid (TsOH). The $\mathrm{Co}(\mathrm{II})($ salen) pre-catalyst $(R, R)-\mathbf{4}(3.5 \mathrm{mg}, 0.005 \mathrm{mmol}$ on the basis of cobalt, $0.01 \mathrm{~mol} \%)$ was charged to a $25 \mathrm{~mL}$ flask. A solution of $p$-toluenesulfonic acid monohydrate in THF $(0.01 \mathrm{M}, 0.55 \mathrm{~mL}, 0.0055 \mathrm{mmol}, 1.1$ equiv) was added and the reaction mixture was stirred in the open air for $30 \mathrm{~min}$, during which time the color changed from deep red to deep green. The solvent was roughly removed by rotary evaporation. The residue was pumped under vacuum (1 mbar) for 5 min to give $(R, R)-\mathbf{4}(\mathrm{OTs})$ as a deep green solid. The activated catalyst was dissolved in racemic allyl glycidyl ether $(5.71 \mathrm{~g}, 50 \mathrm{mmol})$ (in the cases of kinetic studies, chlorobenzene was added as an internal reference for the GC analysis). The flask was immersed into a water bath at ambient temperature and deionized water $(0.54 \mathrm{~mL}, 30 \mathrm{mmol}, 0.60$ equiv) was added to the system to start the reaction. The resolution process was monitored by chiral GC method. After the reaction was stirred at $\mathrm{rt}$ for $6 \mathrm{~h}$, the remaining epoxide was vacuum-transferred $\left(40{ }^{\circ} \mathrm{C}, 0.15 \mathrm{mbar}\right)$ to a receiving flask pre-cooled at $-78{ }^{\circ} \mathrm{C}$. The recovered epoxide was passed through a plug of silica gel packed in a Pasteur pipet to give $(R)$-allyl glycidyl ether as a clear colorless liquid (2.62 g, 46\%) in >99\% ee according to chiral GC analysis. 


\section{2 (R)-1,2-Epoxyhexane (Table 1, Entry 1)}

Method A: In the presence of $(R, R)-\mathbf{4}(\mathrm{OAc})$ prepared from $(R, R)-\mathbf{4}(7.0 \mathrm{mg}, 0.01$ mmol on the basis of cobalt, $0.01 \mathrm{~mol} \%)$ and acetic acid $(20 \mu \mathrm{L})$ in dichloromethane (1.0 $\mathrm{mL})$, the hydrolytic kinetic resolution of racemic 1,2-epoxyhexane (10.0 g, $100 \mathrm{mmol})$ with water (1.08 mL, $60 \mathrm{mmol}, 0.60$ equiv) at $\mathrm{rt}$ for $2.5 \mathrm{~h}$ afforded $(R)-1,2$-epoxyhexane as a clear colorless liquid $(4.28 \mathrm{~g}, 43 \%)$ in $>99 \%$ ee $\left(\gamma\right.$-TA, $50{ }^{\circ} \mathrm{C}$, isothermal, $t_{\mathrm{R}}(R$, major $)$ $=9.7 \mathrm{~min}, t_{\mathrm{R}}(S$, minor $\left.)=9.1 \mathrm{~min}\right)$ after the vacuum transfer $(\mathrm{rt}, 0.2 \mathrm{mbar})$ and the subsequent dehydrate treatment.

\section{3 (S)-Epichlorohydrin (Table 1, Entry 2)}

Method A: In the presence of catalyst $(R, R)-\mathbf{4}(\mathrm{OAc})$ prepared from $(R, R)-\mathbf{4}(7.0$ $\mathrm{mg}, 0.01 \mathrm{mmol}$ on the basis of cobalt, $0.01 \mathrm{~mol} \%)$ and acetic acid $(20 \mu \mathrm{L})$ in dichloromethane $(1.0 \mathrm{~mL})$, the hydrolytic kinetic resolution of racemic epichlorohydrin $(9.25 \mathrm{~g}, 100 \mathrm{mmol})$ with water $(1.08 \mathrm{~mL}, 60 \mathrm{mmol}, 0.60$ equiv) at $\mathrm{rt}$ for $2.5 \mathrm{~h}$ afforded (S)-epichlorohydrin as a clear colorless liquid $(4.09 \mathrm{~g}, 44 \%)$ in $>99 \%$ ee $\left(\gamma\right.$-TA, $55{ }^{\circ} \mathrm{C}$, isothermal, $t_{\mathrm{R}}(S$, major $)=10.1 \mathrm{~min}, t_{\mathrm{R}}(R$, minor $\left.)=11.6 \mathrm{~min}\right)$ after the vacuum transfer $(\mathrm{rt}$, $0.2 \mathrm{mbar}$ ) and the subsequent dehydrate treatment.

Method B: In the presence of catalyst $(R, R)-\mathbf{4}(\mathrm{OTs})$ prepared from $(R, R)-\mathbf{4}(7.0 \mathrm{mg}$, $0.01 \mathrm{mmol}$ on the basis of cobalt, $0.01 \mathrm{~mol} \%$ ) and $p$-toluenesulfonic acid monohydrate in THF (0.01 M, $1.1 \mathrm{~mL}, 0.011 \mathrm{mmol}, 1.1$ equiv), the hydrolytic kinetic resolution of racemic epichlorohydrin $(9.25 \mathrm{~g}, 100 \mathrm{mmol})$ with water $(1.08 \mathrm{~mL}, 60 \mathrm{mmol}, 0.60$ equiv) 
at $\mathrm{rt}$ for $2.5 \mathrm{~h}$ afforded $(S)$-epichlorohydrin as a clear colorless liquid $(3.97 \mathrm{~g}, 43 \%$ ) in $>99 \%$ ee after the vacuum transfer (rt, 0.2 mbar) and the subsequent dehydrate treatment.

\section{4 (S)-Glycidyl Phenyl Ether (Table 1, Entry 4)}

Method A: In the presence of catalyst $(R, R)-\mathbf{4}(\mathrm{OAc})$ prepared from $(R, R)-\mathbf{4}(7.0$ $\mathrm{mg}, \quad 0.01 \mathrm{mmol}$ on the basis of cobalt, $0.01 \mathrm{~mol} \%)$ and acetic acid $(20 \mu \mathrm{L})$ in dichloromethane $(1.0 \mathrm{~mL})$, the hydrolytic kinetic resolution of racemic glycidyl phenyl ether $(15 \mathrm{~g}, 100 \mathrm{mmol})$ with water $(1.08 \mathrm{~mL}, 60 \mathrm{mmol}, 0.60$ equiv) was carried out at $\mathrm{rt}$ for $1 \mathrm{~h}$ and $40{ }^{\circ} \mathrm{C}$ for $19 \mathrm{~h}$. The remaining $(S)$-glycidyl phenyl ether was collected by vacuum distillation $\left(60{ }^{\circ} \mathrm{C}, 0.14\right.$ mbar) as a clear colorless liquid $(6.87 \mathrm{~g}, 46 \%)$ in $>99 \%$ $e e\left(\right.$ Chiracel OD, isopropanol $/$ hexanes $=10 / 90(\mathrm{v} / \mathrm{v}), t_{\mathrm{R}}(S$, major $)=12.0 \mathrm{~min}, t_{\mathrm{R}}(R$, minor $)$ $=7.8 \mathrm{~min})$.

Method B: In the presence of catalyst $(R, R)-\mathbf{4}(\mathrm{OTs})$ prepared from $(R, R)-4(7.0 \mathrm{mg}$, $0.01 \mathrm{mmol}$ on the basis of cobalt, $0.01 \mathrm{~mol} \%$ ) and $p$-toluenesulfonic acid monohydrate in THF (0.01 M, $1.1 \mathrm{~mL}, 0.011 \mathrm{mmol}, 1.1$ equiv), the hydrolytic kinetic resolution of racemic glycidyl phenyl ether $(15 \mathrm{~g}, 100 \mathrm{mmol})$ with water $(1.08 \mathrm{~mL}, 60 \mathrm{mmol}, 0.60$ equiv) was carried out at $\mathrm{rt}$ for $1 \mathrm{~h}$ and $40{ }^{\circ} \mathrm{C}$ for $5 \mathrm{~h}$. The remaining $(S)$-glycidyl phenyl ether was collected by vacuum distillation $\left(60{ }^{\circ} \mathrm{C}, 0.14\right.$ mbar $)$ as a clear colorless liquid $(6.58 \mathrm{~g}, 44 \%)$ in $>99 \%$ ee.

\section{5 (R)-Styrene Oxide (Table 1, Entry 5)}

Method A: In the presence of catalyst $(R, R)-\mathbf{4}(\mathrm{OAc})$ prepared from $(R, R)-4(35 \mathrm{mg}$, $0.05 \mathrm{mmol}$ on the basis of cobalt, $0.1 \mathrm{~mol} \%)$ and acetic acid $(50 \mu \mathrm{L})$ in dichloromethane 
$(2.0 \mathrm{~mL})$, the hydrolytic kinetic resolution of racemic styrene oxide $(6.01 \mathrm{~g}, 50 \mathrm{mmol})$ with water ( $0.54 \mathrm{~mL}, 30 \mathrm{mmol}, 0.60$ equiv) and acetic acid ( $30 \mu \mathrm{L}, 0.5 \mathrm{mmol}, 0.01$ equiv) was carried out at $\mathrm{rt}$ for $24 \mathrm{~h}$. The remaining $(R)$-styrene oxide was collected by vacuum distillation $\left(40{ }^{\circ} \mathrm{C}, 0.12\right.$ mbar) into a pre-cooled receiving flask $\left(-78{ }^{\circ} \mathrm{C}\right)$ as a clear colorless liquid $(2.71 \mathrm{~g}, 45 \%)$ in $>99 \%$ ee ( $\beta$-Dex, temperature programming: $80{ }^{\circ} \mathrm{C} 5$ $\min , 80{ }^{\circ} \mathrm{C}$ to $120{ }^{\circ} \mathrm{C}$ at $4{ }^{\circ} \mathrm{C} / \mathrm{min}, 120{ }^{\circ} \mathrm{C} 10 \mathrm{~min} ; t_{\mathrm{R}}(R$, major $)=18.4 \mathrm{~min}, t_{\mathrm{R}}(S$, minor $)=$ $18.9 \mathrm{~min})$.

Method B: In the presence of catalyst $(R, R)-\mathbf{4}(\mathrm{OTs})$ prepared from $(R, R)-\mathbf{4}(35 \mathrm{mg}$, $0.05 \mathrm{mmol}$ on the basis of cobalt, $0.1 \mathrm{~mol} \%$ ) and $p$-toluenesulfonic acid monohydrate in THF (0.01 M, $5.5 \mathrm{~mL}, 0.055 \mathrm{mmol}, 1.1$ equiv), the hydrolytic kinetic resolution of racemic styrene oxide $(6.01 \mathrm{~g}, 50 \mathrm{mmol})$ with water $(0.54 \mathrm{~mL}, 30 \mathrm{mmol}, 0.60$ equiv) was carried out at $\mathrm{rt}$ for $2.5 \mathrm{~h}$. The remaining $(R)$-styrene oxide was collected by vacuum distillation $\left(40{ }^{\circ} \mathrm{C}, 0.12\right.$ mbar) into a pre-cooled receiving flask $\left(-78{ }^{\circ} \mathrm{C}\right)$ as a clear colorless liquid (2.87 g, 48\%) in >99\% ee.

\section{6 (R)-tert-Butyloxirane (Table 1, Entry 6)}

Method A: In the presence of catalyst $(R, R)-\mathbf{4}(\mathrm{OAc})$ prepared from $(R, R)-\mathbf{4}(88 \mathrm{mg}$, $0.125 \mathrm{mmol}$ on the basis of cobalt, $0.25 \mathrm{~mol} \%)$ and acetic acid $(100 \mu \mathrm{L})$ in dichloromethane $(4.0 \mathrm{~mL})$, the hydrolytic kinetic resolution of racemic $t$-butyloxirane $(5.01 \mathrm{~g}, 50 \mathrm{mmol})$ with water $(0.54 \mathrm{~mL}, 30 \mathrm{mmol}, 0.60$ equiv) at $\mathrm{rt}$ for $48 \mathrm{~h}$ afforded $(R)$ $t$-butyloxirane as a clear colorless liquid $(2.08 \mathrm{~g}, 42 \%)$ in $98.1 \%$ ee according to chiral $\mathrm{GC}$ analysis $\left(\gamma-\mathrm{TA}, 40{ }^{\circ} \mathrm{C}\right.$, isothermal, $t_{\mathrm{R}}(R$, major $)=7.2 \mathrm{~min}, t_{\mathrm{R}}(S$, minor $\left.)=7.9 \mathrm{~min}\right)$ after the vacuum transfer (rt, 0.2 mbar) and the subsequent dehydrate treatment. 


\section{In situ ${ }^{1} \mathrm{H}$ NMR Spectra of the Ring-Expanding Olefin Metathesis of 7}

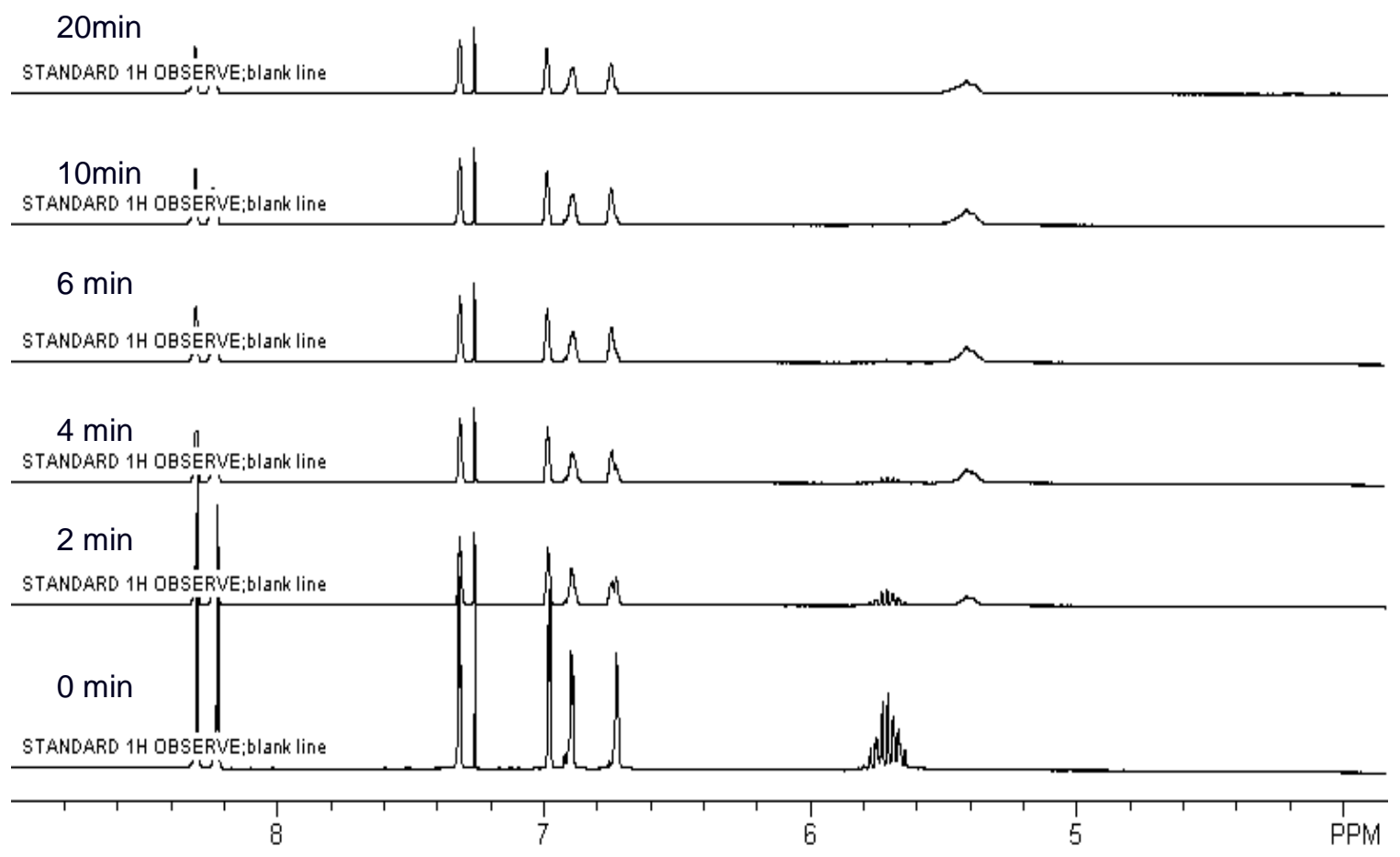

Figure S1. In situ ${ }^{1} \mathrm{H}$ NMR spectra of the ring-expanding olefin metathesis of 7 


\section{GPC Traces}

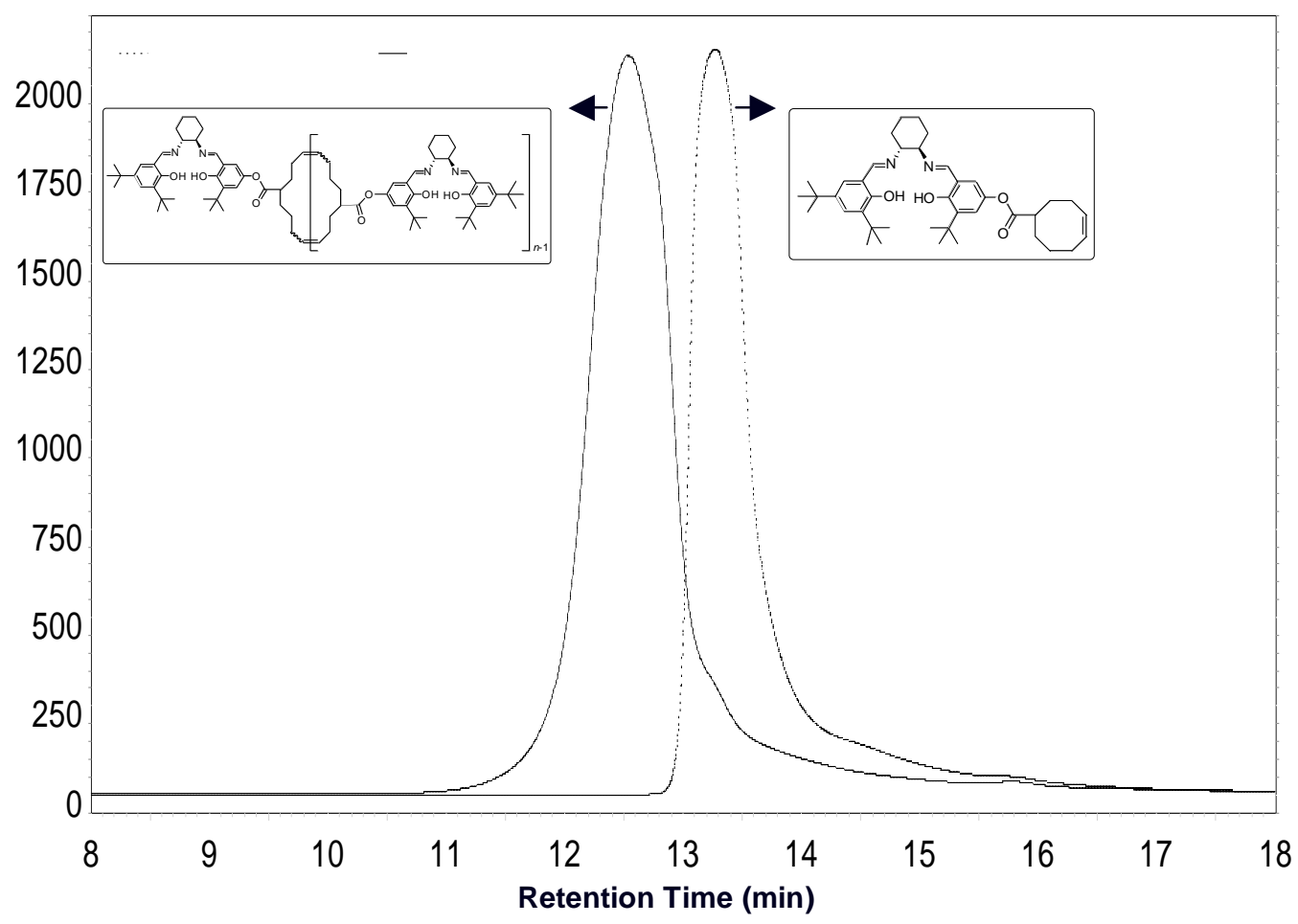

Figure S2. GPC Traces of Monomer 7 and Oligomer 8

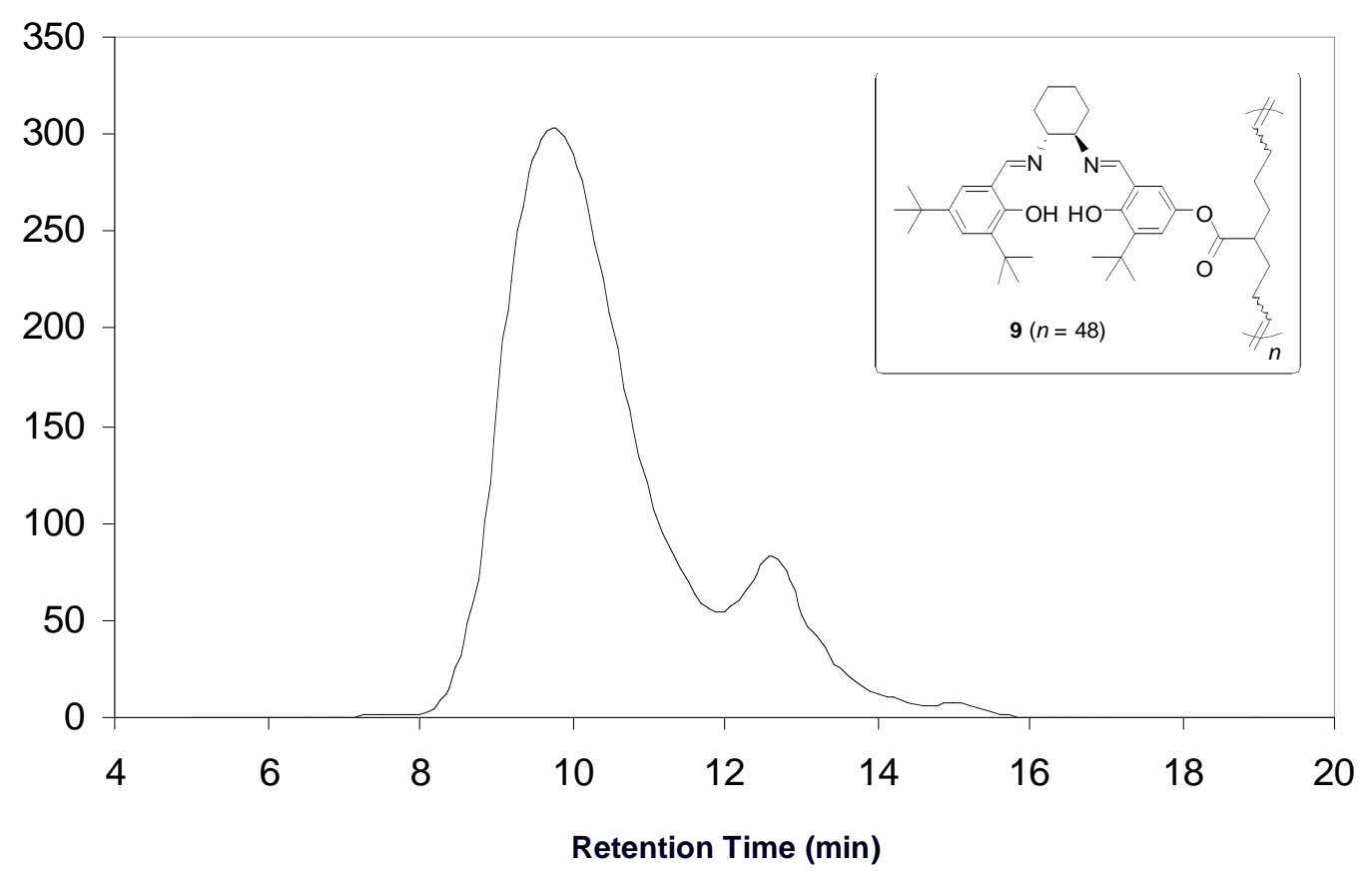

Figure S3. GPC Trace of Polymer 9 

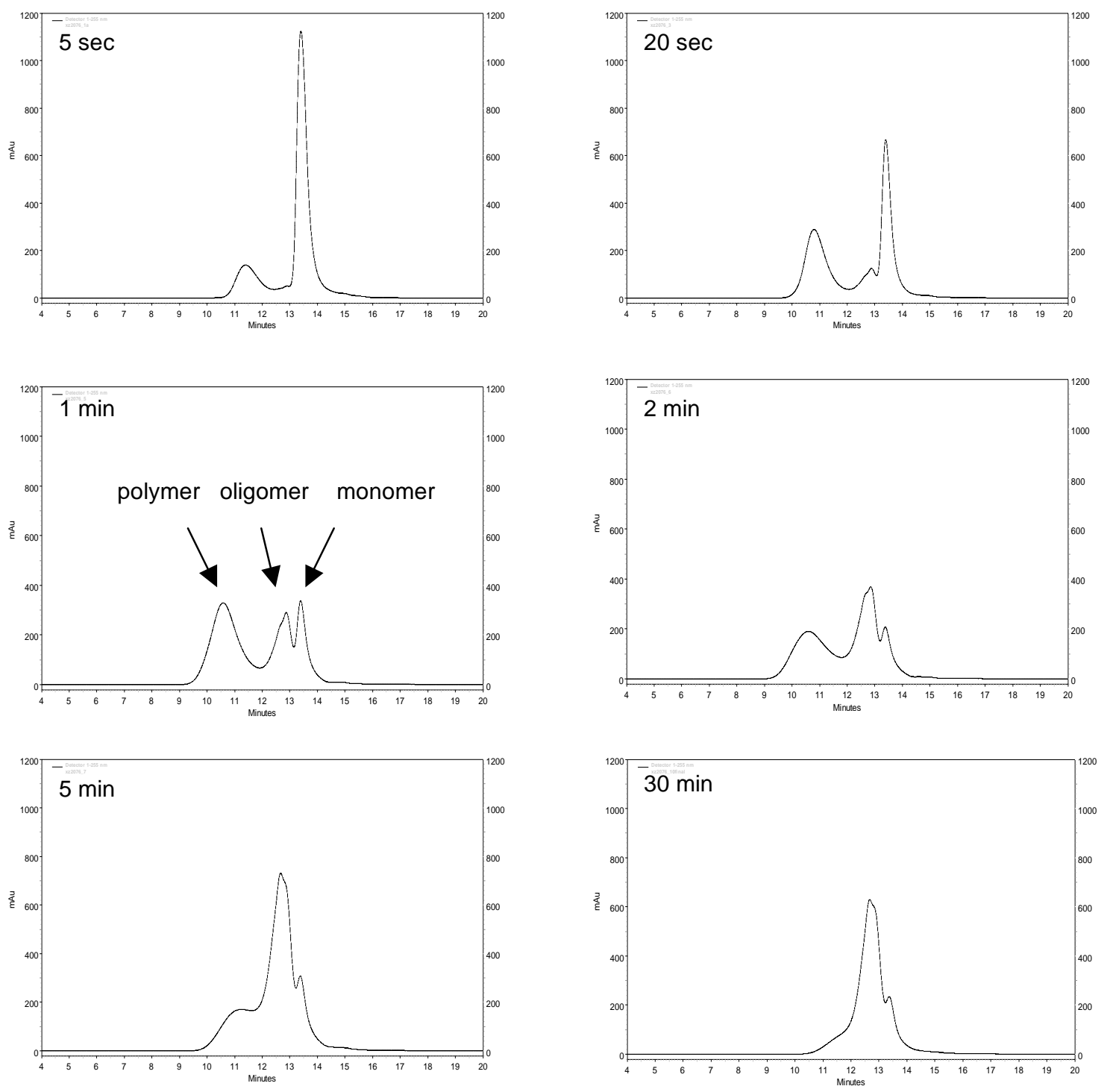

Figure S4. Ring-Expanding Olefin Metathesis of Monomer 7 at a Concentration of 0.1 M as Monitored by GPC. 


\section{References}

(1) Ready, J. M.; Jacobsen, E. N. J. Am. Chem. Soc. 2001, 123, 2687-2688.

(2) Ashby, E. C.; Coleman, D. J. Org. Chem. 1987, 52, 4554-4565.

(3) Ziegler, K.; Wilms, H. Ann. 1950, 567, 1-43.

(4) Holbach, M.; Zheng, X.; Burd, C.; Jones, C. W.; Weck, M. J. Org. Chem. 2006, 71, 2903-2906.

(5) Love, J. A.; Morgan, J. P.; Trnka, T. M.; Grubbs, R. H. Angew. Chem. Int. Ed. 2002, $41,4035-4037$. 